\title{
Reform and Practice of Application-oriented Talents Cultivation Mode against the Background of New Engineering
}

\author{
Shi Junwei, Chen Zhangliang \\ School of Management Science and Engineering, Shandong Institute of Business and Technology \\ Yantai, 264005, China \\ Shijunwei302@126.com
}

\begin{abstract}
Socio-economic development and the demand of talents' unceasing changes have raised higher expectations for the quality of professional training in higher education institutions. The talents training mode has also proposed the further innovation and reform. Based on the Safety Engineering's high level applied professional education practice in Shandong Technology and Business University, this paper analyses the main channel for realizing the applied talents training of Safety Engineering under the background of 'new engineering', and it aims to provide a reference for colleges and universities of applied talents training mode and basis, provides interdisciplinary talents with practical ability for high and new technology industry in society.
\end{abstract}

Keywords-The new engineering; Safety engineering; Application-oriented talents; Cultivation mode; Teaching mode

\section{INTRODUCTION}

"New engineering" is a new strategy for the reform of education in the new period of our country. First of all, it is China's new economy's urgent need of implement for the strategy of innovation. The "Internet +", "industrial manufacturing 4.0" , "made in China 2050" led to rapid development of the new generation of information technology, electric power equipment, high-end $\mathrm{CNC}$ machine tools and robots, new materials, new technology of virtual reality, and modern biological technology, the related emerging industries and innovative enterprises need a large number of engineering practice ability, innovation ability, have the international competitiveness of high quality new engineering talents[1]. At present, the industry engineering talent's gap is huge. Second, it is also the reality demand of reforms of the higher education in China, in 2016, the national engineering undergraduate students were 5.38 million people, 1.23 million graduates, the stationing was 17037, professional engineering students were about a third of the total number of college students. Our country already has the world's largest engineering education. However, there is a large gap between the traditional engineering school and the international engineering education standard [2].

In 2015, the state education department issued < Guidence on leading parts of ordinary undergraduate colleges and universities to applied ones>, put forward that the transformation of development was a major measure for deepening the reform of higher education field comprehensive, strategic level has been clear about the ordinary undergraduate course of colleges and universities in the country of the development of the new path.

\section{APPLICATION-ORIENTED TALENT CULtivation Mode}

\section{A. Making solid progress in the project of "outstanding engineers" and innovativing talent training mode.}

Continuing to carry out research on project excellence; Improving the modular curriculum system and corporate culture standards of the "excellent engineer program"; Carrying out the reform of teaching method, making the teaching plan design meet the talent training knowledge, ability and quality requirement [3]; Establishing an effective school-enterprise joint training mechanism, and creating a distinctive training mode for application-oriented talents [4]; Promoting engineering education professional certification, to create a brand of excellence. Playing the "excellence initiative" demonstration effect, promoting safety engineering applied talents training mode reform, building social demand as the guidance, in order to improve the students' engineering ability as the core of practical, innovative talent training system and explore the training mode, training professional characteristics [5].

\section{B. Reforming the teaching method, training the student independent study ability.}

In view of the current university classroom "just one person's saying" and "cramming education", teachers are hard while students just suffer from them. Most of students are lack of learning autonomy and their abilities are weakened [6]. With application of the theory of cognitive psychology, it changes the "single into single out" of the traditional teaching mode, cooperative learning and comprehensive excellent classroom teaching mode is proposed [7]. It aims to play the role of teaching in the classroom which it should be, to enhance students' participation in class, and train the students' comprehensive ability in many aspects [8]. Focus on taking the actual case as the object and explain the specific work principle function and process through case's analysis. Its purpose is clear. Through the project teaching method, theoretical explanation, experimental teaching, engineering practice and 
innovation activities are integrated. In one or more of the teaching module, we tell it around a typical enterprise actual problem. According to the task driving mode integrating the teaching content to optimize, teachers should tell how much according to students need. The ability are related all elements. The comprehensive utilization of various methods plays the overall benefit of different methods.

The content of the course and teaching methods complement exist by each other. The contents have been reformed and the teaching methods have to be reformed. The correct use of teaching methods will promote the construction of a modular curriculum system. The majors of the professional group have studied and reformed the teaching methods such as the workshop teaching method, the project accompanying teaching method, the problem-based teaching method (PBL), the case teaching method, etc., but how to make the teacher use different teaching methods according to the different contents of the module is a diversified teaching method that needs further study.

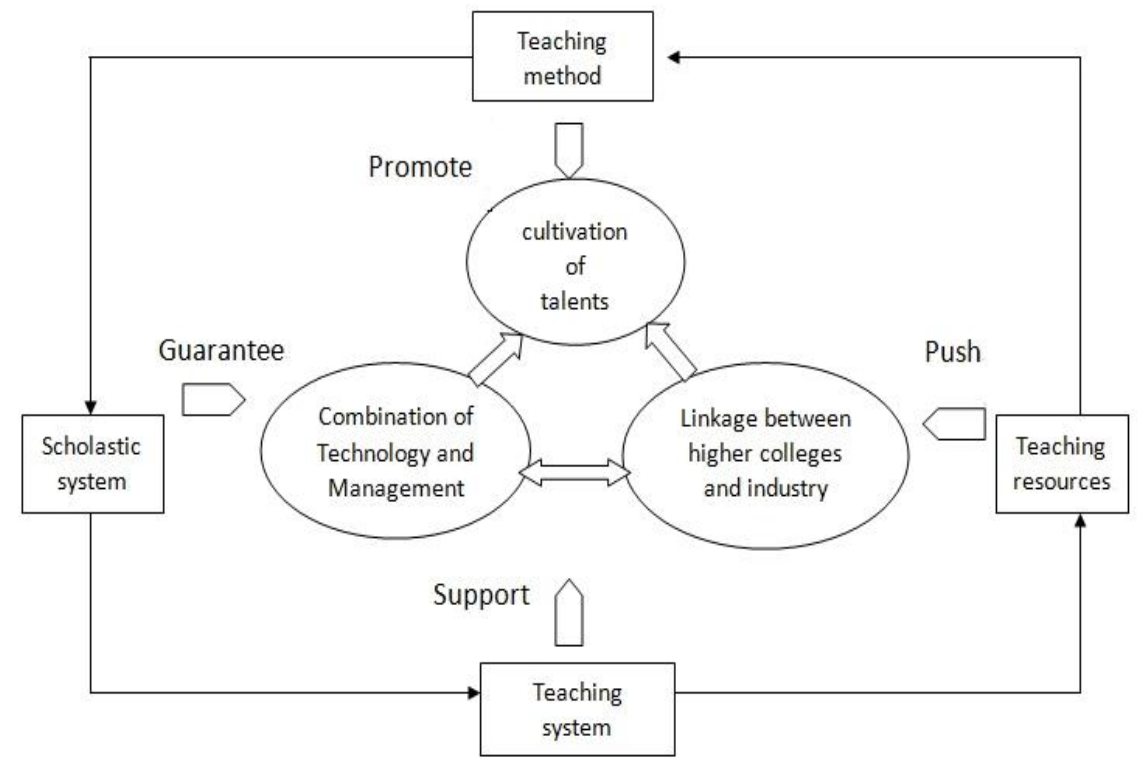

Fig. 1. The training mode of composite applied talents in colleges and universities.

\section{Strengthening practical teaching and deepening the cultivation of school-enterprise cooperation.}

In order to cultivate students' application ability and practical innovation ability, the experimental teaching system is constructed [9]. We should strengthen the laboratory and practical base construction, integrate experimental teaching resources and establish a new experimental teaching platform for application-oriented personnel training; We will actively promote school-enterprise, school-level, intercollegiate joint construction practice, practical training base, and broaden practical teaching channels.

To deepen school-enterprise cooperation training, we will carry out various forms of joint education with enterprises, industries and government departments, and innovate the sustainable development mechanism of close cooperation with industry and enterprises [10]. To establish long-term and stable cooperation mechanism with industry, enterprises and government in the development and implementation of talent training programs, construction of internship bases, innovation and entrepreneurship education.

\section{Strengthening the construction of high-quality courses and building the applied modular teaching materials.}

We will vigorously strengthen the standard curriculum, school-level quality courses, and the three-level curriculum system for provincial high-quality courses, and comprehensively implement the system of principals of the curriculum (group). We will focus on the construction of highquality courses, give full play to the demonstration role of high-quality courses, and promote the construction of major courses, subjects and courses of specialized courses and online courses. We will strengthen the construction of the "curriculum center" auxiliary teaching platform and implement the standard course online plan. It is proposed that quality engineering and human engineering should be taken as school-level excellent courses, and the introduction of safety engineering will result in provincial quality courses, and the national quality courses will be the ultimate goal.

It adopts the state-level key planning teaching materials and the 21 st century teaching materials. Faster development of course content to the specialized courses and professional direction course (compulsory or limited optional courses), with nearly three years of high quality teaching materials published by the state, the rate of textbooks for more than $80 \%$.

In school adjustment, the transformation of academic disciplines and teaching reform as the backing, with students' 
innovative spirit and practice ability training as the core, to encourage teachers to carry out the quality engineering management, logistics engineering, advanced manufacturing and simulation and so on three big modules applied modular teaching material construction, and participate in professional teaching plan or write published materials independently.

\section{E. Actively carrying out the second classroom teaching work.}

We will carry out various forms of science and technology innovation practice, combine the theory courses with experiment practice teaching and students' science and technology innovation activities. We will also encourage the student to carry on the various forms of extracurricular design and production. Organizing students to participate in all kinds of competitions, and cultivate students' design interest, practical ability, engineering consciousness and innovative spirit and team spirit.

Modules are divided according to professional group schedule and function, such as feasibility study module, on-site management module, optimization tool module and so on. The composition of the module is to break the boundaries of the traditional curriculum, based on the professional sub-capacity and then optimize, integrate and reorganize the original curriculum content, and at the same time introduce the industry's latest technology and norms in the module construction, the integrated module content-oriented ability cultivation, and the needs of the industry's enterprises. The docking of professional capabilities not only avoids duplication of the content between modules, but also enables the application of knowledge, application, and use. The system responsible for the establishment of the module, responsible for the module responsible for the construction of the module and module content updates. During the construction period, 8-10 modular courses will be constructed, such as on-site management modularization of industrial enterprises, modularization of engineering project evaluation, and modularization of enterprise safety management.

\section{F. Strengthening the construction of teaching staff.}

Through intensive cultivation and positive introduction, we will improve the educational level of the teachers' team, and at the end of the planning and construction period, $100 \%$ of the teachers will have a graduate degree or above.

By constantly supplementing young and middle-aged teachers, the age structure of full-time teachers is relatively reasonable, and the average age of full-time teachers is about 40 years old. Through the implementation of teachers' employment system, the professional title structure of full-time teachers is constantly adjusted to make teachers' professional titles more reasonable and meet the needs of teaching research and development. By broadening the sources of teachers, strengthening the construction of "double type" teachers, encouraging teachers crossover study or to the enterprise study, improving teachers' learning structure, we will make the "double type" teachers above 50\%. To further expand the international vision of teachers, we make our teachers who have overseas visits to study or work experience more than 30 percent.
Because the teaching of the modular curriculum needs to optimize, integrate and reorganize the teaching content, the traditional textbook cannot meet the teaching needs. The construction of the textbook has become the key to the reform of the modular curriculum system. Although there is no such thing as a fixed textbook, the introduction of the industry's latest technologies and industry standards and specifications is an essential part of modular curriculum content. As an active intermediary, teachers use their own professional capabilities to integrate the original knowledge, the latest cutting-edge technologies, and the standards of the industry to form a textbook with a rich and modular connotation.

\section{G. Strengthening laboratory construction and practice base construction.}

Safety engineering specialty experimental teaching at present is mainly professional basic experiment courses. The existing equipments basically meet the professional basic experiment teaching of this major and most of the professional teaching of experiment course. After 2016, we will strengthen the construction of laboratories and quality engineering laboratory, make this professional not only is a high-tech equipment, but also make the device has reached the high update rate. Meanwhile we will also make the contents of this professional in comprehensive and designing experiments and levels will have a greater degree of improving. After 5 years of construction, the laboratory has become a leading and advanced level of innovation base, talent training base and technology service achievement transformation base in the manufacturing field. Efforts will be made to build laboratories and practice bases into a platform for teaching, research and social technology services. Promoting the synchronization of "industry-university-research", so as to achieve teaching and teaching.

Further improving the management system of the professional laboratory and the open experimental teaching mode; At the same time, the laboratory is open to the outside world, and trains a large number of special talents for enterprises and institutions. In addition, we should strengthen the construction of experimental teachers and build a laboratory team with high quality, comprehensive technology, reasonable structure and relatively stable personnel.。

We will strengthen the construction of off-campus practice base, establish a relatively stable specialty and the practice base of "excellent engineer" education training. Through off-campus internship, the students will have a necessary understand to the enterprises and institutions of modern equipment, production technology and scientific management. The organic combination of theory and practice will help them lay a good foundation to shorten from school to social adaptation. In the teaching and research work, the safety engineering discipline attaches great importance to the relationship between development and local enterprises. Over the years, we have cooperated with weigao group to build student internship base, which has ensured the smooth progress of practical teaching and cultivated students' ability to solve practical problems. 


\section{H. Strengthening the quality monitoring of teaching process and optimizing the learning effect evaluation.}

By strengthening the quality monitoring of teaching process , and make the responsibility consciousness distinct enhancement, teaching process standardization, procedural execution process, standardization of work results. Through the efficient and effective teaching quality monitoring system, we enhance teachers' sense of responsibility, arouse the enthusiasm of teaching work.

The evaluation system of teaching and learning effect is an effective guarantee to measure the students' learning knowledge, ability, learning attitude and monitoring teacher's teaching behavior. The evaluation method is diversified, and the learning effect can be divided into small test, examination, course paper, course design, design report defense, etc. On the content of the assessment, it emphasizes the ability, practice ability and innovation ability of the students to comprehensively apply knowledge. After instructing teachers to analyze and evaluate the relevant data of learning effect, it is necessary to give feedback to the teaching process. Optimization of scientific and reasonable evaluation system can ensure that students can meet the requirements of the teaching goal, supervise and urge students to independent participation, truly promote the cultivation of the innovative applied talents, to ensure the quality of personnel training.

The module is a free combination of teaching activities around a specific topic or content, and therefore it has a very flexible feature. This flexible feature makes the module curriculum resources extremely rich, and will constitute the modules to form a "module pool." The modules in the "module pool" can be flexibly used in different professions to realize the sharing of resources between schools and schools, as well as to provide students with personalized development. The school will also use the opportunity of information platform construction to build and enrich the teaching resources network sharing platform, integrate effective resources, use MOOC resources to build various types of open courses for the Internet, enhance the dissemination of knowledge, and realize the sharing of curriculum resources. During the construction period, 5-10 network courses will be constructed.

\section{IMPLEMENTATION EFFECT AND SUMMARY}

In training plan revision, while the owner to safety engineering graduates is building, chemical and other industrial production line, the basic requirement of industrial enterprises for graduates is the ability to practice, therefore, we must be innovative applied talents training mode to adapt to the industrial enterprises. In the eight term of 4 years of schooling,it should be scientific and reasonable integration of theoretical teaching and practical teaching, the school teaching and enterprise internal teaching schedules, so we can make it accord with the goal of talent cultivation. On this major project of cultivating applied talents revision, we continue to compress theory lessons, raise the proportion of practice teaching, make the proportion of total credits credits in specialty practice teaching is greater than $30 \%$, completed the 2017 edition of the talent training scheme.
In university-enterprise cooperation, we respectively make a partnership with qixia city strong mining machinery co., LTD and shandong Aberdeen security consulting services co., LTD., the cooperation is focused on students' graduation practice and the formulation of the talent training scheme, argument, etc., and establish the safety engineering practice base.

In terms of students' participation in scientific research subject, we encourage students to actively participate in teachers' scientific research subject, students participate in research projects including "coal gangue cemented filling mining gypsum body safety studies (2013 qn001), lane stowing mining strata movement and surface subsidence rule research qn014 (2015), the evaluation system of green mining coal enterprises competitiveness research qn015 (2015), and other teacher's school youth fund projects [11].

In terms of students' participation in social practice, ma yaru and Yang yuting are the summer volunteer teachers of the north wudang boarding primary school in luliang city, Shanxi Province; Chu yanpeng studys on the policy of water storage and treatment; $\mathrm{Li}$ siqi has winter vacation social practice of shandong classic heavy industry group co., LTD; Huang lina does a survey report on rural land use.

\section{CONCLUSION}

Under the background of new engineering, the social industry can develop in the direction of high and new science and technology. At present, the engineering science and technology talent cultivation in colleges and universities faces the imperfection of the practice for the construction of relevant systems and mechanisms, the impetus for nurturing high quality applied talents is insufficient, university-enterprise cooperation in practical training is not enough in depth and such problems. We should realize the combination of teaching content and teacher's scientific research in teaching mode, the combination of teachers and students, the combination of theoretical knowledge and practical skills, the combination of the first class and second class, such as the combination of "four combinations". We will give full play to the advantages of local universities and local industries, reform the original teaching mode and the practical teaching framework, update the content of the course and increase the program and content of the course training, project practice and enterprise training. We will also actively use enterprise fund to hold a joint student management practices, management innovation competition, set up the studio used to train the student management, expand the practice bases to provide broad platform for the student management practice. Then we can cultivate innovative and versatile talents for colleges and universities under the new engineering background. 


\section{ACKNOWLEDGMENT}

This research was financially supported by Teaching Reform Project of Shandong Business School: A Study on Hybrid Teaching Model and Evaluation System Based on Application-oriented Talent Cultivation (Grant NO. 1168G201701) , 2016 "CAD Engineering Drawing" of the Project of Blended Teaching Course of Shandong Business School (Grant NO. 04021203) and Shandong Natural Science Foundation: Research on enterprise informatization introduction mode and enterprise value increment oriented to supply and demand network(Grant NO. ZR2012GM003).

\section{REFERENCES}

[1] Xiong Sujuan. Construction and implementation of a new hybrid teaching model based on "flipped classroom" [J]. Vocational education newsletter, 2016, (6):61-66.

[2] Wu kunfu. Development and application of higher vocational courses based on three-dimensional interactive hybrid learning $[\mathrm{J}]$.Education and occupation, 2014, (32):139-141.

[3] Zhang lina. Construction and implementation of the hybrid teaching mode of hvac courses based onmicro-course environment $[\mathrm{J}]$. Journal of Ningbo institute of engineering, 2016, (02):91-95.

[4] Chen Xiliang, Jiang Feng, Lai Jun, Peng Wei. Research on college computer basic teaching reform based on hybrid teaching model [J]. Computer education, 2016, (06):143-146.

[5] Yang bai can. The practice of mixed teaching in Chinese medicine micro-course teaching [J]. TCM education, 2014, (06):32-34.

[6] Cao Xuhong. The application of hybrid teaching model in law teaching - taking the course of law of labor law and social security as an example [J]. Law and society, 2015, (34):236-237.

[7] Shi Shugui, Zhang Changjiang, Li Xiaotong, Zhao Yuhua. The influence of hybrid teaching mode on improving college students' English reading ability [J]. Overseas English, 2016, (08):86-87.

[8] Guoxinyi. The application of hybrid teaching inadult education [J]. Adult education, 2016, 36 (08):13-15.

[9] Feng Shigang, Wang roujian. The constructive postmodernism orientation of hybrid teaching $[\mathrm{J}]$. Journal of hebei radio \& TV university,2016, (03):59-61

[10] Pei Xiaoqin, Xia Chunming, Du Longbing. Research on the evaluation system of mixed teaching effect from the perspective of MOOC [J]. Future and development, 2015, (11):96-98.

[11] Lei jing. "Market research and research" teaching reform and practice [J] Market journal (theoretical research), 2010, (12):103-104. 